\title{
Da revolta de Jeú à guerra siro-efraimita: os reinados de Israel na pesquisa recente
}

\author{
Orientadora: Prof ${ }^{a}$. Maria de Lourdes Corrêa Lima
}

Pesquisador: Willian Gomes Mendonça

Fonte: $\mathrm{CNPq}$

Introdução

Foi realizado um estudo a partir dos textos bíblicos como base para compreensão da ação drástica de Jeú em Israel em consonância com os estudos da arqueologia tradicional e arqueologia recente. Procurou-se fazer uma síntese textual dos autores estudados e do texto bíblico. A partir desta base, buscou-se confrontar o texto bíblico com a arqueologia tradicional e recente e descobrir o que o autor bíblico quer transmitir ao escrever a história de Israel de uma forma em parte diferente do dado histórico.

\section{Objetivo}

Estudar a visão bíblica a partir da segunda metade do século IX e do século VIII até a guerra siro-efraimita confrontando os textos bíblicos com os da arqueologia histórica tradicional e recente, a fim de pôr em relevo a intenção teológica dos textos bíblicos. 